\title{
Esophagus and Esophagogastric Junction Cancer PTX TNM Finding v7
}

National Cancer Institute

\section{Source}

National Cancer Institute. Esophagus and Esophagogastric Junction Cancer pTX TNM

Finding v7. NCI Thesaurus. Code C89725.

Esophagus and esophagogastric junction cancer in which the primary tumor cannot be assessed. (from AJCC 7th Ed.) 